\title{
KEMAMPUAN SELF-EFFICACY MAHASISWA MELALUI BAHAN AJAR METODE STATISTIKA MENGGUNAKAN HYBRID LEARNING PADA TANTANGAN REVOLUSI INDUSTRI 4.0
}

\author{
Sowanto $^{1}$, Andang ${ }^{* 1}$, Mutmainnah ${ }^{1}$, Hasdin Adi Saputra ${ }^{2}$ \\ ${ }^{1}$ Department of Mathematics Education, STKIP Bima, Jl. Piere Tendean, Bima, \\ Indonesia \\ ${ }^{2}$ Guru Komputer dan Jaringan, SMKN 1 Kempo, Jl. Lintas Soro Calabai, Dompu, \\ Indonesia \\ *Email korespondensi: andangumm2@gmail.com
}

\begin{abstract}
ABSTRAK
Penelitian ini didasarkan pada permasalahan belum adanya studi sebelumnya tentang kemampuan Selfefficacy (keyakinan diri) mahasiswa program studi pendidikan matematika dalam menyelesaikan masalah yang berhubungan dengan statistika pada mata kuliah metode statistika. Untuk mengatasi hal tersebut, dilakukan penelitian pengembangan bahan ajar mata kuliah metode statistika menggunakan Hybrid Learning sesuai tantangan Industri 4.0. Adapun yang dikaji dalam penelitian ini adalah masalah self-efficacy mahasiswa setelah perkuliahan metode statistika diberikan menggunakan Hybrid Learning. Penelitian ini merupakan penelitian preexperimental dengan desain penelitian menggunakan one-shot case studi. Subjek penelitian ini adalah seluruh mahasiswa semester III mata kuliah metode statistika program studi pendidikan matematika tahun ajaran 2019/2020 salah satu perguruan tinggi swasta di Kota Bima. Instrumen yang digunakan dalam penelitian ini berupa angket self-efficacy. Hasil penelitian menunjukkan bahwa self-efficacy matematis mahasiswa yang pembelajarannya menggunakan Hybrid learning berada pada kategori "yakin", berarti mahasiswa yakin untuk mampu menyelesaikan tugas-tugas yang dikembangkan pada bahan ajar yang diberikan melalui Hybrid Learning, baik ditinjau secara keseluruhan maupun ditinjau pada dimensi magnitude, strength, maupun generality.
\end{abstract}

Kata kunci: self-efficacy, hybrid learning, revolusi industri 4.0.

\begin{abstract}
This research is based on the problem of the absence of previous studies on the ability of Selfefficacy in students of mathematics education courses in solving problems related to statistics in statistics methods courses. To overcome this, research on the development of teaching materials in statistical methods using Hybrid Learning is in line with Industry 4.0 challenges. As for what was studied in this study was the problem of student self-efficacy after lecturing the statistical method was given using Hybrid Learning. This research is a pre-experimental study with a research design using a one-shot case study. The subjects of this study were all the third semester students of the statistical methods courses in the mathematics education study program 2019/2020 school year one private university in the City of Bima. The instrument used in this study was a self-efficacy questionnaire. The results showed that the mathematical self-efficacy of students whose learning using Hybrid Learaning was in the "confident" category, meant that students were confident of being able to complete the tasks developed on teaching materials provided through Hybrid Learning, both as a whole and reviewed on the magnitude dimension, strength, and generality.
\end{abstract}

Keywords: self-efficacy, hybrid learning, industrial revolution 4.0. 


\section{PENDAHULUAN}

Matematika ditinjau dari arah kebijakan pendidikan nasional merupakan salah satu program dalam kesatuan ilmu yang mendukung pencapaian tujuan pendidikan nasional dalam mencerdaskan kehidupan bangsa dan mengembangkan manusia Indonesia seutuhnya.

Di era revolusi industri 4.0, kompleksitas dan semakin ketatnya persaingan dunia kerja memberikan tuntutan pada program pendidikan matematika untuk mampu mengembangkan lagi proses melalui kegiatan pembelajaran yang mampu menumbuhkembangkan kemampuan beripikir yang tidak hanya terpaku pada penilaian hasil pembelajaran dari aspek kognitif semata, melainkan juga pada aspek afektif dan psikomotor. Ketiga aspek yaitu kognitif, afektif dan psikomotor dalam taksonomi Bloom merupakan kecakapan matematika yang mempunyai andil untuk bersinergi dalam keberhasilan anak pada proses pembelajaran matematika. Dengan kata lain, peningkatan setiap aspek tidak terkecuali aspek afektif yaitu aspek psikologis yang berhubungan attitude siswa juga memiliki peranan yang sama (Mulyana dalam Kusumah, 2018).

Bila ditinjau dalam keberhasilan belajar mahasiswa, peranan aspek afektif akan berdampak pada prestasi dan kinerja, sebab afektif memfasilitasi mahasiswa untuk mampu memberikan penilaian awal terhadap diri sendiri melalui interaksi antara faktor tingkah laku, pribadi, dan lingkungannya. Penilaian awal terhadap diri sendiri atau tingkat keyakinan akan kemampuannya ini berkaitan dengan self-efficacy yang akan sangat mempengaruhi proses belajar matematika mahasiswa. Dalam menghadapi tantangan yang diberikan dalam proses belajar matematika, self-efficacy akan menentukan perilaku atau tindakan yang dipilih, ketekunan, serta pola berpikir dan reaksi emosional.

Mahasiswa dengan Self-efficacy yang tinggi, pada umumnya akan memberikan dampak lebih mudah dan berhasil melampaui latihan-latihan matematika yang diberikan kepadanya, sehingga hasil akhir dari pembelajaran tersebut yang tercermin dalam prestasi akademiknya juga cenderung akan lebih tinggi dibandingkan siswa yang memiliki self-efficacy rendah (Pajares, 2002: 11). Hal ini sesuai dengan yang yang diungkapkan Fennema dan Sherman (dalam Cleary, Breen, O’Shena, 2010) bahwa keyakinan pada kemampuan seseorang untuk belajar matematika ditemukan memiliki korelasi positif yang kuat dengan prestasi matematika.

Dalam proses perkuliahan matematika, mahasiswa dituntut untuk berhasil dalam menyelesaikan tugas dan pertanyaan-pertanyaan pemecahan masalah matematis yang 
diberikan. Self-efficacy mempengaruhi tindakan, upaya, ketekunan, fleksibilitas dalam perbedaan dan realisasi dalam tujuan dari individu (Bandura, 1997). Self-efficacy membuat mahasiswa secara mental menyiapkan pengetahuan dalam bentuk kontruksi berpikir awal guna menyelesaikan masalah matematis yang diberikan berdasarkan pengetahuannya tentang masalah yang dihadapi.

Dosen memiliki peranan dalam memfasilitasi mahasiswa agar mampu mengembangkan kemampuan self-efficacy yang dimilikinya dengan memberikan kesempatan kepada mahasiswa untuk secara langsung mengkontruksi konsep matematika yang dipelajari sesuai situasi nyata yang pernah dialami dan sesuai dengan kondisi lingkungan mereka. Kusumah (2018) mengungkapkan bahwa seorang pendidik dituntut untuk mampu berinovasi menciptakan perangkat pembelajaran yang mampu menumbuhkembangkan kemampuan anak dalam pembelajaran matematika. Dalam rangka mempersiapkan mahasiswa terutama mahasiswa matematika yang kompetitif sehingga mampu berkiprah di masyarakat, salah satu inovasi yang bisa dilakukan oleh dosen yaitu mengembangan bahan ajar yang dirancang tidak lagi hanya dilakukan melalui tatap muka di kelas (face to face), melainkan sebagaimana yang diungkapkan Pratiwi, Suwono, dan Handayani (2014), bisa dikembangkan juga pembelajaran yang merupakan kombinasi pembelajaran melalui tatap muka di kelas dan pembelajaran daring (e-learning) yang dikenal dengan hybrid learning.

Pada pembelajaran dengan hybrid learning, mahasiswa dituntut belajar mandiri dan berkelanjutan sehingga pembelajaran akan menjadi lebih efektif, efisien, dan menarik. Hal ini menguatkan perlunya dikembangkan bahan ajar pada mata kuliah metode statistika dengan hybrid learning yang berorientasi KKNI di era evolusi industri 4.0 sebagai langkah inovatif karena baru pertama dikembangkan pada program studi pendidikan matematika salah satu perguruan tinggi swasta di Kota Bima, yang hasilnya diharapkan memberikan dampak dalam pengembangan bahan ajar mata kuliah lain.

\section{METODE PENELITIAN}

Penelitian ini dirancang dengan Pre-experimental Design. Adapun desain yang digunakan dalam penelitian ini adalah dengan One-shot Case Study. Untuk rancangan Preexperimental Design dengan One-shot Case Study. Desain Pre-experimental Design dipilih sesuai dengan yang diungkapkan Sugiyono (2013) bahwa desain ini belum merupakan eksperimen sungguh-sungguh, sebab masih terdapat variabel luar yang ikut berpengaruh 
terhadap terbentuknya variabel dependen. Jadi hasil eksperimen yang merupakan variabel dependen dalam hal ini yaitu kemampuan self-efficacy mahasiswa bukan semata-mata dipengaruhi oleh variabel independen yaitu bahan ajar yang dikembangkan. Hal ini dapat terjadi, karena tidak adanya variabel kontrol serta sampel tidak dipilih secara random. Adapun desain penelitian ini adalah sebagai berikut:

\section{$\mathbf{X} \mathbf{O}$}

\section{Keterangan:}

X : Pembelajaran dengan bahan ajar metode statistika dengan Hybrid Learning yang dikembangkan sesuai tantangan revolusi industri 4.0

\section{O : Kemampuan self-efficacy mahasiswa}

Subjek dalam penelitian ini adalah seluruh mahasiswa semester III mata kuliah metode statistika program studi pendidikan matematika tahun ajaran 2019/2020 pada salah satu perguruan tinggi swasta di Kota Bima. Subjek penelitian ini merupkan subjek yang dijadikan tempat ujicoba bahan ajar yang telah dikembangkan. Dalam pelaksanaannya, penelitian ini menggunakan instrumen nontes berupa angket self-efficacy dalam bentuk pernyataan yang diberikan kepada mahasiswa pada akhir kegiatan pembelajaran dengan mengakses secara online link google form untuk mengisi angket. Tujuan dari pemberian angket ini adalah untuk mengukur tingkat keyakinan mahasiswa terhadap kemampuannya dalam melaksanakan tindakan-tindakan yang diperlukan ketika menghadapi persoalan matematis maupun terhadap pembelajaran matematika.

Angket self-efficacy matematis mahasiswa dalam penelitian ini difokuskan pada tiga dimensi pengukuran dengan mengadaptasi instrumen self-efficacy yang dikembangkan oleh Sudrajat (2008) yaitu 1) magnitude atau level yang berhubungan dengan tingkat keyakinan siswa dalam menentukan tingkat kesulitan soal matematis yang dihadapi; 2) strength berhubungan dengan tingkat keyakinan siswa terhadap kemampuannya dalam mengatasi masalah yang muncul ketika menyelesaikan soal matematis; dan 3) generality yang berhubungan dengan tingkat keyakinan siswa dalam menggeneralisasikan tugas dan pengalaman sebelumnya.

Pada angket online yang diberikan untuk setiap item pernyataan digunakan skala interval 1-4, dimana angka 1 untuk menunjukan mahasiswa sangat tidak yakin, 2 untuk tidak yakin , 3 untuk yakin, dan 4 ketika siswa sangat yakin dengan butir pernyataan yang dijawab. 
Adapun sebelum angket self-efficacy matematis mahasiswa ini digunakan merupakan angket yang sudah dimodifikasi dengan menyesuaikan dengan hybrid learning dari angket yang sebelumnya telah dilakukan uji coba instrumen self-efficacy matematis siswa terhadap 30 orang siswa dengan menggunakan rumus Alpha Cronbach pada program Microsoft Excel 2010 dan diperoleh koefisien reliabilitas angket adalah 0,949. Kesimpulan dari hasil uji coba bahwa angket self-efficacy yang digunakan memiliki reliabilitas yang sangat tinggi. Hal ini berarti bahwa angket yang diajukan memiliki keakuratan dan ketepatan dalam mengukur kemampuan self-efficacy matematis mahasiswa yang hendak diuji.

\section{HASIL DAN PEMBAHASAN}

Penelitian ini bertujuan untuk menelaah dan mendeskripsikan kemampuan self-efficacy matematis mahasiswa setelah mendapatkan pembelajaran dengan bahan ajar yang telah dikembangkan menggunakan Hybrid Learning. Tujuan dari analisis hasil self-efficacy akhir mahasiswa untuk melihat gambaran self-efficacy mahasiswa setelah mendapat perkuliahan dengan bahan ajar yang telah dikembangkan. Adapun hasil dapat dilihat pada Tabel 1 di bawah ini.

Tabel 1 Rerata Self-Efficacy Matematis Mahasiswa ditinjau secara keseluruhan

\begin{tabular}{ccc}
\hline $\boldsymbol{n}$ & rerata & Keterangan \\
\hline 16 & 3 & Yakin \\
\hline
\end{tabular}

Dari tabel di atas terlihat bahwa nilai rerata dari respon atau jawaban mahasiswa secara keseluruhan dari dimensi self-efficacy adalah pada angka 3. Hal ini berarti, kemampuan selfefficacy matematis mahasiswa setelah mendapatakan pembelajaran dengan bahan ajar yang dikembangkan menggunakan Hybrid Learning berada pada kategori Yakin. Dengan kata lain, mahasiswa memiliki tingkat keyakinan yang tinggi dalam menyesaikan tugas-tugas dari bahan ajar yang diberikan melalui Hybrid Learning.

Data self-efficacy matematis siswa selain dianalisis secara keseluruhan, tetapi juga dianalisis berdasarkan dimensinya, dengan tahapan yang sama dengan tahapan analisis data secara keseluruhan. Berikut pembahasan self-efficacy matematis siswa dilihat dari dimensi Magnitude atau Level, Strength, dan Generality. 
Hasil perhitungan rerata data self-efficacy matematis siswa berdasarkan dimensi magnitude/level secara lengkap dapat dilihat pada Tabel 2 berikut.

Tabel 2 Rerata Data Self-Efficacy Matematis Siswa Berdasarkan Dimensi Magnitude/Level

\begin{tabular}{ccc}
\hline $\boldsymbol{n}$ & rerata & Keterangan \\
\hline 16 & 3 & Yakin \\
\hline
\end{tabular}

Dari tabel di atas terlihat bahwa nilai rerata dari respon atau jawaban mahasiswa dilihat dari dimensi magnitude atau level adalah pada angka 3. Hal ini berarti, kemampuan selfefficacy matematis mahasiswa setelah mendapatakan pembelajaran dengan bahan ajar yang dikembangkan menggunakan Hybrid Learning berada pada kategori Yakin untuk dimensi magnitude atau level. Dengan kata lain, pada dimensi magnitude atau level mahasiswa memiliki tingkat keyakinan yang tinggi dalam menyesaikan tugas-tugas yang dikembangkan pada bahan ajar yang diberikan melalui Hybrid Learning.

Untuk nilai self-efficacy matematis matematis siswa berdasarkan dimensi strength hasil perhitungan reratanya secara lengkap dapat dilihat pada Tabel 3 berikut ini.

Tabel 3 Rerata Data Self-Efficacy Matematis Siswa Berdasarkan Dimensi Strength

\begin{tabular}{ccc}
\hline $\boldsymbol{n}$ & rerata & Keterangan \\
\hline 16 & 3 & Yakin \\
\hline
\end{tabular}

Dari tabel di atas terlihat bahwa nilai rerata dari respon atau jawaban mahasiswa dilihat dari dimensi strength adalah pada angka 3. Hal ini berarti, kemampuan self-efficacy matematis mahasiswa setelah mendapatakan pembelajaran dengan bahan ajar yang dikembangkan menggunakan Hybrid Learning berada pada kategori Yakin untuk dimensi strength. Dengan kata lain, pada dimensi strength mahasiswa memiliki tingkat keyakinan yang juga tinggi dalam menyesaikan tugas-tugas yang dikembangkan pada bahan ajar yang diberikan melalui Hybrid Learning. 
Dilihat dari dimensi generality, self-efficacy matematis matematis siswa hasil perhitungan reratanya secara lengkap dapat dilihat pada Tabel 4 berikut.

Tabel 4 Rerata Data Self-Efficacy Matematis Siswa Berdasarkan Dimensi Generality

\begin{tabular}{ccc}
\hline $\boldsymbol{n}$ & rerata & Keterangan \\
\hline 16 & 3 & Yakin \\
\hline
\end{tabular}

Dari tabel 4 di atas terlihat bahwa nilai rerata dari respon atau jawaban mahasiswa dilihat dari dimensi generality adalah juga sama dengan dimensi magnitude maupun strength yaitu 3. Hal ini berarti, pada dimensi generality kemampuan self-efficacy matematis mahasiswa setelah mendapatakan pembelajaran dengan bahan ajar yang dikembangkan menggunakan Hybrid Learning juga berada pada kategori Yakin. Dengan kata lain, pada dimensi generality mahasiswa memiliki tingkat keyakinan yang tidak berbeda dengan tingkat keyakinan pada dimensi magnitude maupun strength yaitu pada kategori tingkat keyakinan yang tinggi dalam menyesaikan tugas-tugas yang dikembangkan pada bahan ajar yang diberikan melalui Hybrid Learning.

Hasil penelitian menunjukkan bahwa secara keseluruhan kemampuan self-efficacy matematis mahasiswa setelah mendapatakan pembelajaran dengan bahan ajar yang dikembangkan menggunakan Hybrid Learning berada pada kategori "yakin". Dengan kata lain, mahasiswa memiliki tingkat keyakinan yang tinggi dalam menyesaikan tugas-tugas dari bahan ajar yang diberikan melalui Hybrid Learning. Adapun lebih jauh untuk mengetahui faktor lain yang memberikan pengaruh dari keyakinan mahasiswa dalam perkuliahan dengan menggunakan bahan ajar yang diberikan belum bisa diketahui. Hal ini disebabkan karena pada penelitian ini belum dilakukan juga wawancara langsung untuk mengetahui faktor lain yang juga berpengaruh terhadap pengambilan keputusan mahasiswa dalam proses pembelajaran dengan Hybrid Learning.

Hasil penelitian ditinjau dari dimensinya, diperoleh bahwa dari ketiga dimensi selfefficacy matematis siswa, kemampuan self-efficacy matematis mahasiswa setelah mendapatkan pembelajaran dengan bahan ajar yang dikembangkan menggunakan Hybrid Learning semuanya berada pada kategori "yakin". Dengan kata lain, mahasiswa memiliki tingkat keyakinan yang berada pada kategori "yakin" untuk mampu menyelesaikan tugas- 
tugas yang dikembangkan pada bahan ajar yang diberikan melalui Hybrid Learning baik pada dimensi magnitude, strength, maupun generality. Lebih lanjut, menurut teori yang disampaikan Suherman (2003) bahwa pembentukan daerah afektif (sikap) sebagai hasil belajar relatif lebih lambat daripada pembentukan daerah kognitif dan psikomotorik, karena perubahan daerah afektif (sikap) memerlukan waktu yang lebih lama dan merupakan akibat dari pembentukan pada daerah kognitif dan psikomotorik. Dengan kata lain, perbaikan rancangan jumlah perkuliahan dari yang dirancang hanya 5 kali untuk bisa melihat lebih jelas kemampuan self-efficacy matematis mahasiswa setelah mendapatkan pembelajaran dengan bahan ajar yang dikembangkan menggunakan Hybrid Learning akan menjadi fokus dalam pengembangan bahan ajar selanjutnya.

\section{KESIMPULAN}

Berdasarkan hasil penelitian, diperoleh kesimpulan bahwa self-efficacy matematis mahasiswa yang pembelajarannya menggunakan Hybrid learaning berada pada kategori "yakin" untuk mampu menyelesaikan tugas-tugas yang dikembangkan pada bahan ajar yang diberikan melalui Hybrid Learning, baik ditinjau secara keseluruhan maupun ditinjau pada dimensi magnitude, strength, maupun generality.

\section{REKOMENDASI}

Berdasarkan hasil dan pembasahan serta kesimpulan penelitian ini, diajukan beberapa rekomendasi yaitu:

1. Bagi peneliti lain yang ingin mengkaji pengaruh Hybrid Learning terhadap self-efficacy siswa agar lebih memperhatikan lama pelaksanaan penelitian dan direkomendasikan waktu penelitian yang digunakan adalah satu semester.

2. Untuk mengetahui lebih spesifik tingkatan self-efficacy siswa direkomendasikan selain menggunakan angket juga dilakukan wawancara secara individu.

\section{UCAPAN TERIMAKASIH}

Dalam penyusunan penelitian ini tidak terlepas dari dukungan berbagai pihak. Peneliti mengucapkan terima kasih kepada semua pihak yang telah memberikan banyak masukan dalam pengembangan dan penyusunan penelitian ini, serta kepada Ibu Dewi Sartika, S. Pd., M. Pd atas kesediaan kelasnya sebagai tempat pengembangan bahan ajar. 


\section{REFERENSI}

Bandura, A. (1997). Self-Efficacy: Toward a Unifying Theory of Behavioral Change. Psychological Review 1977, 84(2), hlm. 191-215.

Cleary, J., Breen, S., O'Shea, A. (2010). Mathematical Literacy and Self-Efficacy of FirstYear Third Level Student. MSOR Connections, 10(2). [Online]. Diakses dari http://www.heacademy.ac.uk/assets/documents/subjects/ msor/1024_Cleary_j_eta_mathliteracy.pdf

Kusumah, Y. S. (2018, May). Enhancing students' mathematical representation and selfefficacy through situation-based learning assisted by geometer's sketchpad program. In Journal of Physics: Conference Series (Vol. 1013, No. 1, p. 012107). IOP Publishing.

Pajares, F.(2002). Overview of Social Cognitive Theory and of Self-Efficacy. [Online]. Diakses dari http://www.emory.edu/education/mfp/eff.html.

Pratiwi, H . E, Suwono, H, \& Handayani, N. (2014). Pengembangan Modul Pembelajaran Biologi Berbasis Hibrid Learning Untuk Meningkatakan Kemampuan Berpikir Kritis Dan Hasil Belajar Siswa Kelas XI. Jurnal Pendidikan Biologi Indonesia, (online), http://Jurnalonline. um. ac. id, 2014 - jurnal-online.um.ac.id. diakses 21 Agustus 2018.

Sudrajat, D. (2008). Program Pengembangan Self-Efficacy Bagi Konselor di SMA Negeri SeKota Bandung. (Tesis). Sekolah Pascasarjana Universitas Indonesia, Bandung.

Sugiyono. (2013). Metode Penelitian Pendidikan: Pendekatan Kuantitatif, Kualitatif, dan $R \& D$. Bandung: Alfabeta.

Suherman, E. dkk. (2003). Strategi Pembelajaran Matematika Kontemporer. Bandung: Jurusan Pendidikan Matematika FPMIPA UPI. 